\title{
Class Room Action Research in English Language Learning
}

\author{
Zulfikri Betyar Rasuan \\ Fakultas Tarbiyah \\ IAIN Syaikh Abdurrahman Siddik Bangka Belitung, Indonesia \\ zulfikri_br@yahoo.co.id
}

\begin{abstract}
Research activities is common for a lecturer because it is a compoulsary term. Research in English Language or English learning is a scientific activity that aims at investigating the rules that work in the process of English learning. Research activities in English learning cover four steps: observing, describing, analyzing, and explaining. The way of each step is done depends on the nature of the data and the objective of the research. Classroom Action Research (CAR) for English Learning aims at developing a certain instructional strategy to solve practical instructional problems in English classrooms. Each English learner is basically able to learn English provided that he or she is given the appropriate help as each learner has his or her own style and strategy of learning. CAR for English Learning aims at discovering learning-teaching strategies that match learners' style and strategies in learning English. CAR is done in several cyles each of which is repeated in the following cycle if the result is not satisfactory yet with the better revised lesson plan. Each cycle begins with lesson planning, implementing the plan, observing the implementation, and reflecing or evaluating the process and the result of the implementation. The result of the reflection determines the following cycle.
\end{abstract}

Key words: Planning, implementation, observation, reflection.

\section{INTRODUCTION}

English languange is compoulsary subject in Indonesia, it was learnt by students and people for their fluency of English language. In Indonesian University English is a base of learning for everything and for the lecturer they should know or at least they should understand what people state. English is very esesential in university life for example in the lecturer research.

The writer wanted to explain how to make a research by using English Language so make other lecturer understand how to make it correctly. 
What is classroom action research? Classroom action research begins with a question or questions about classroom experiences, issues, or challenges. It is a reflective process which helps teachers to explore and examine aspects of teaching and learning and to take action to change and improve.

Classroom action research begins with a question or questions about classroom experiences, issues, or challenges. It is a reflective process which helps teachers to explore and examine aspects of teaching and learning and to take action to change and improve.

English Learning Research (ELR) is a scientific academic activity in the form of an investigation or investigation of a ELR process with the aim of being able to better understand the ELR process. Understanding a ELR process means being able to explain the systems, rules, patterns, regularity, formulas, rules of ELR (Marshall \& Rossman, 1995: 16). Every researcher who is researching ELR assumes that ELR follows a certain system, rules, patterns, regularities, formulas, or tips. And on the basis of these tips, ELR can succeed. These tips are tried by researchers to uncover.

ELR research activities differ from the activities of journalists who observe ELR classes whose job is only to record factual information from the ELR in the form of descriptions that are ready to become news to be presented to readers ( ${ }^{1}$ Bogdan \& Biklen, 1998: 37). The researcher, after observing and recording the results of his observations, analyzes the results of his observations (research data) using the ELR scientific paradigm that he has until finally able to explain the tips that exist in the ELR that is being studied.

ELR researchers are at the forefront of the ELR knowledge development chain because they are exploring and discovering knowledge directly from ELR classes. The findings of the ELR researchers were collected to be classified and recorded in writing in the form of books or journals that are ready to be read by others. The second group (collectors of research results) classifies all ELR research findings in the form of rules about ELR in one body of knowledge.

The third group involved in the ELR development chain process is the readers; namely students majoring in English Education and ELR lecturers. This group of readers reads information contained in books, discusses in class, in seminars, workshops, and so on.

${ }^{1}$ Bogdan, RC \& Biklen, S.K. 1998. Qualitative Research in Education. An Intoduction to Theory and Method. Boston : Allyn and Bacon 
This article explains (1) the general ELR activity process which includes observation, description, analysis, and explanation; (2) ELR research approach that explains in general the differences between research with quantitative data and research with qualitative data; (3) classroom action research which includes several repetitive cycles, each of which includes the stages of planning, action, observation, and reflection. This article also explains; (4) the difference between classroom action research and experimental research in the ELR process. Also emphasized in this article is an explanation of; and (5) key terms in each CAR that have a special meaning in CAR, namely: planning that contains the problem to be solved and the strategy to be developed; observations which contain the process of collecting data which can be in the form of interviews, questionnaires, observations, tests, and so on; and reflection which contains data analysis and evaluation of data analysis results to see whether or not it is necessary advanced cycle, and if necessary continued cycle, which part of the learning strategy or technique being developed needs to be improved.

\section{ENGLISH LANGUAGE RESEARCH ACTIVITIES}

English Language Research (ELR) activities basically consist of 4 stages, namely (1) observation, (2) description, (3) analysis, and (4) explanation. The observation stage is the stage of data collection that can be done in various forms according to the nature of the observed data, including interviews, questionnaires, observations, tests, identification, and so on.

The purpose of observation is to collect data that includes indicators or signs that can help researchers understand the ELR under study. If what is studied is student achievement in learning English at school related to the sex of the student, for example, what is observed from the student (research object) is the student's (variable) gender and the student's English learning achievement that is the object of the study. To observe (variable) the gender of students, observations can be made by looking at gender indicators, such as how to dress, ornaments used, mustache, neck shape, chest shape, sound, how to walk, and so on. By looking at these indicators researchers can classify male students and grouping female students. To observe the achievement of learning outcomes in English, researchers can also view records of student learning progress owned by the teacher or the researcher can provide an English test. From the teacher's notes or from the 
results of these tests, researchers can find student achievement, from students with low achievements to those who have high achievement.

The description phase consists of recording the results of observations (data collection). Examples of research on the relationship of junior high school English learning achievement with their gender, which need to be recorded are a list of male student groups, a list of female student groups, and a list of English scores of all students who are the object of the study.

The next step is data analysis. At this stage the results of the description (which become data) are analyzed with certain techniques according to the nature of the data and the purpose of the study. In the sample research on the relationship of students' English learning achievement with gender, analysis can be done with the Statistics formula to compare the mean scores of male student learning outcomes and the average scores of female students.

The last stage is the explanation, understanding, or drawing conclusions. At this stage the activities carried out by researchers are giving meaning or interpreting the results of the analysis. In the example of research on the relationship of junior high school students' English learning achievement with gender, if the results of the analysis show that the average English scores of female students are much higher (striking differences) than the mean English scores of male students, for example, the researcher concludes (gives meaning, explain) that gender influences students' learning achievement in English, namely students girls tend to perform better in learning English than male students.

\section{ENGLISH LANGUANGE RESEARCH APPROACH}

How the research process (observation, description, analysis, explanation) is done depends on the nature of the data and research objectives. Research activities that aim to understand patterns, systems, rules, or relationships between variables that exist on the object of research, with quantitative data, such as the example of the relationship between English learning achievement of junior high school students with the sex above, can be done in one time cycle / cycle (invest, describe, analyze, and finally conclude).

In qualitative research, (research whose data is not represented by numbers or not quantified, such as research on the development of English sentence patterns junior high school students from first class, second class, and third grade, (in writing, for example) 
research activities are not generated from one time data collection activities, one-time data analysis activities, and then concluded Observation, description, analysis, and explanation activities are carried out repeatedly, so that the conclusions drawn are gradual results from the interim to the final results of several data collection activities, and data analysis which takes place in circulai. Data collection activities consist of some some stages.

1. Data collection step I immediately followed by the data analysis activity (stage I) which produced a temporary conclusion (hypothesis I).

2. Hypothesis I is a temporary conclusion that needs to be confirmed by conducting data collection activities again (stage II), and

3. analyzing data (stage II), so as to produce hypopthesis II. which strengthens (verifies, adds to, or even rejects) hypothesis I. If the conclusions cannot be conclusively drawn from these two hypotheses, then the data collection and data analysis activities in stage III need to be carried out again. And so on until the findings are found that can be trusted.

That's when the hypothesis (after having been revised several times through several cycles) became a research finding.

Research that aims to find the right way, strategy, or procedure to solve a language learning problem needs to be done in several cycles. Each cycle is followed by the next cycle to get better results in accordance with the desired criteria (results). Research activities like this are called Classroom Action Research.

\section{CLASS ROOOM ACTION RESEARCH}

Classroom Action Research is a medium for enhancing teacher and professional abilities for increasing student learning success. In CAR, the teacher evaluates his teaching activities and then makes improvements based on the results of the evaluation. Often changes in learning strategies found by teachers are more easily spread to other teachers (bottom up) compared to changes offered by superiors (top down). Class romm Action Research activities start from the teacher's habit of caring about the success of his teaching activities, or caring about matters relating to the development of student learning, behavior, social interaction, learning difficulties, and learning environment of his students which he 
then evaluates for consideration in preparing corrective action plans, implementing corrective actions, and evaluation of corrective actions ( ${ }^{2}$ Borgia Schuler, 2003).

Teachers on the other hand, must become more and more autonomous in order to provide the students with effective learning opportunities where the students come across their own potentialities to improve themselves. The teacher's duty is to make the learners understand the responsibility of their own education. The forceful thrust of the content matter to the students in the classroom, make the students blind to their own potentials because it is totally a one way, single method oriented and conventional type of teaching. When teaching of a teacher is concerned, it is obvious that a teacher advocates a method pertaining to his or her own way. The formal training and the teacher development courses he or she has followed make no much influence on the way he or she teaches

Action Research Classroom Learning English (ELR) is research that aims to develop (try to find) ELR strategies or techniques that can help students appropriately so that students can master English. Every student in the class basically can master English (there is no single student who can't master English in class) as long as they get guidance with the right strategy or technique. The failure of students in learning English is the failure of teachers to provide English learning guidance appropriately and optimally. The failure of students in learning English is caused by improper and inadequate guidance given by the teacher which is a practical problem for teachers in their assignments to teach English in class. Every English teacher always has this kind of learning problem. Every English teacher must always try to solve problems it faces.

Solving English learning problems is part of the professional task of every English teacher. Efforts to solve this problem can be done with Classroom Action Research (CAR). Thus Class Room Action Research is an inseparable part of learning English in the classroom. With CAR activities, the English teacher tries to solve practical problems in the English learning process encountered by developing certain strategies or techniques. These practical problems include: How to increase students' courage in speaking English in class with learning techniques with drawing media? How to facilitate the learning process of writing students with travel strategies? How do you use guessing games to make students

\footnotetext{
${ }^{2}$ Borgia, Et. \& Schuler,D. 2003. Action Research in Early Childhood Education, (on line)
} 
more active in learning to speak English? How to improve students' motivation to read by using gift-giving techniques?

There are some steps that should be done by researcher . they are :

1. Reflect

Talk to your colleagues. What questions do you have about teaching? What topics are you and your colleagues interested in? Are there problem areas, or aspects of teaching/learning you are all unsure about? Make a list. From your list, decide together the topic for the classroom action research. To help you decide, discuss why you want to do it. What are the benefits to teachers and to learners? When you have decided, write one or two questions about your topic which will guide what you do.

2. Explore

Reflect on your topic questions. Where can you find information to help you plan the research? Do you need to consult published materials or the Internet for information and ideas? Find out as much as you can about the topic to help you plan how to do the action research.

3. Plan

Think about: how long it will the action research take? How will you record the research? There are different ways of doing classroom action research. It can be as simple as just writing down your own reflections relating to the topic after a lesson or sequence of lessons or it could include questionnaires, observations, audio recordings and so on.

4. Research

Carry out the action research using your chosen method. Some ideas are:

- Peer observation

- Teacher diary

- Learner feedback

- Lesson evaluation

- Recording lessons

- Reflecting on learners' work

- Surveys

Choose the method which best suits your topic questions.

5. Researching together 
It is also helpful to carry out action research with a colleague or group of colleagues. This gives you more data to reflect on, compare and discuss.

6. Analyse

This stage helps you to make sense of the data you have collected in your research. It is a process of reflecting on, organising and reviewing your data to help you answer your topic questions. What have you found out? What insights have you gained from the research? What does your research show you?

7. Act

If you have carried out the classroom action research on your own, share your results with your colleagues. Reflect on the results. How do the results help you and your colleagues? What changes will you all make?

8. Review

It is important to review the impact of the changes made. How successful were they? Is any follow-up action needed? Are there any differences amongst your colleagues?

English Class Room Action Research activities are carried out in several cycles. The results of one cycle (because they usually have not reached the desired target) are completed in the next cycle, and so on until the right strategy is found to help student learning (so students can successfully master English with pleasure). Each CAR consists of planning, implementation, observation and reflection. The results of reflection become input on re-planning for the next cycle ${ }^{3}$ (Kemmis \& McTaggert, 1988), as in Figure

\footnotetext{
${ }^{3}$ Kemmis, S. \& Mc Taggert, M. 1998 The Action Research Planner (3rd ed). Vitoria Deakin University
} 


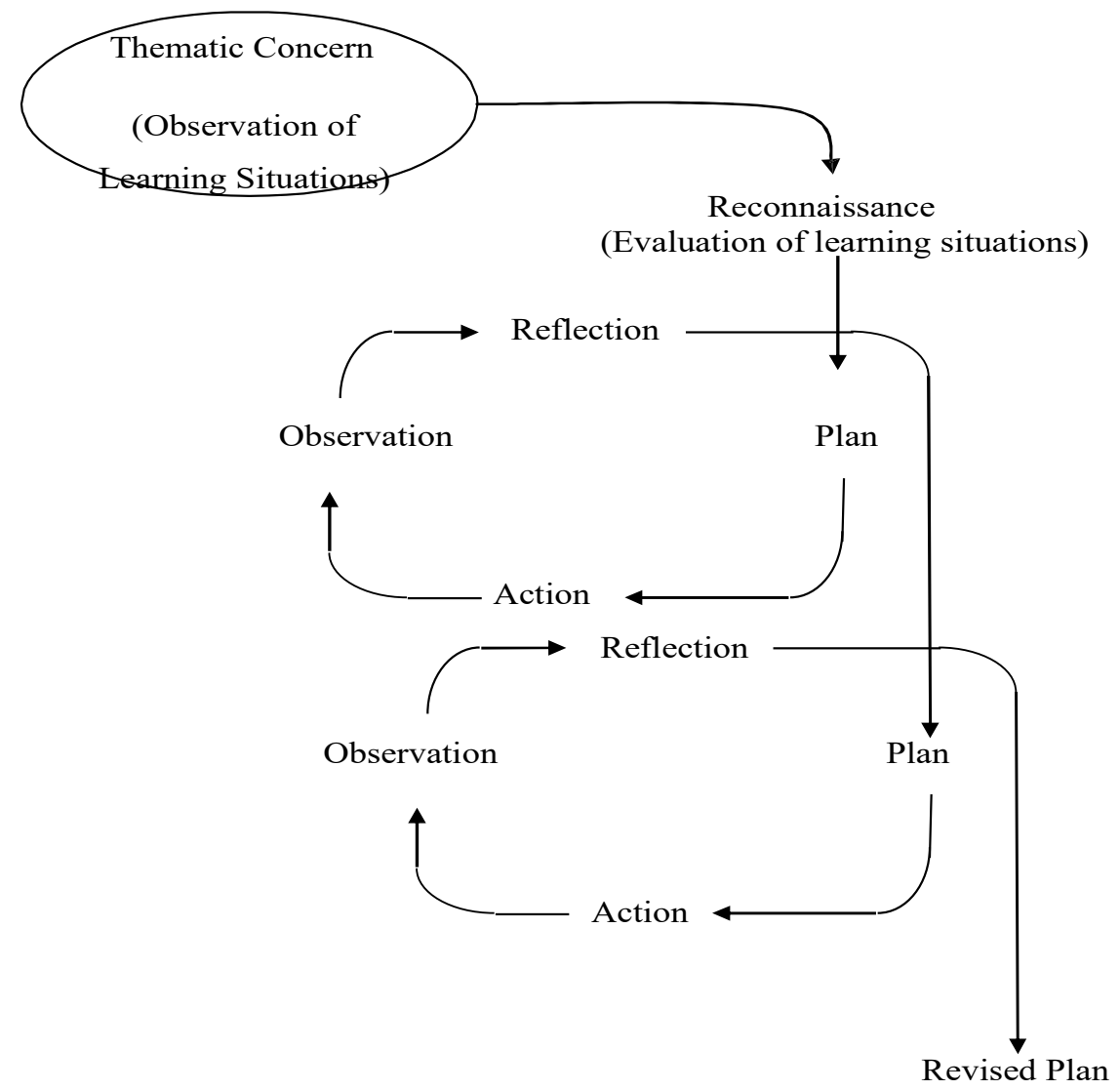

Figure 1: The Action Research Spiral Sources: Kemmis, S., McTaggert, R. (1988)

Action Research Learning (Class Room Action Research Learning English) is different from experimental research. In English Class Room Action Research Learning, the purpose of research is the development of strategies or techniques of learning English that have not yet been developed by other researchers. In experimental research, the purpose of research is to compare among existing (or existing) strategies or techniques developed by others) to find which of these strategies or techniques is most effective. So experimental research aims to compare between established strategies or techniques, while CAR develops strategies or techniques that do not yet exist or have not yet been developed.

In Class Room Action Research ELR a learning strategy or technique was developed to solve practical problems faced by teachers in the classroom. Class Room Action Research regarding the use of travel strategies to facilitate students in learning to 
write in English, for example, will produce learning strategies called Tourism Strategies that have never been developed in the same context. The Tourism Strategy will be formulated in the form of activity steps learning to compose English, then tried out in class, observed and reflected to see whether the strategy has been able to solve the practical problem of learning, namely to facilitate students in the process of learning to write English. If during one trial cycle, the learning problem has not been solved or indicators of success in solving the learning problem have not yet been seen, then the Tourism Strategy will be corrected for later try again, observe, and reflect again, and if necessary the strategy is revised again. And so on until all indicators of success in an effort to solve the learning problem are achieved. So the ELR Class Room Action Research product is an English learning strategy / technique that can solve the learning problems faced by teachers in the classroom.

The TOD process is clearly different from the experimental research process in ELR. In experimental research, the purpose of research is to test the effectiveness of an existing learning strategy / technique (not in the process of being developed) by comparing it with other strategies / techniques. Experimental studies are always done by comparing one group that is treated with a certain learning strategy / technique with another group that is not given the same treatment called the control group ( ${ }^{4}$ Tickman, 1999: 132). The different treatments given to the two groups are called independent variables while the learning outcomes of the two groups treated differently will be compared to see whether the different treatments have an impact on significantly different learning outcomes.

Learning outcomes are compared to the so-called dependent variable. Experimental research thus aims to examine the effect or causal relationship between independent variables and dependent variables by comparing the two groups that are treated in the form of different learning strategies / techniques.

\section{PLANNING}

Planning is a design activity for problem solving. Planning for CAR is made on the basis of :

\footnotetext{
${ }^{4}$ Tickman, B. W. 1999. Conducting Educational Research, Fifth Edition Belmont: Wadsworth Group / Thomson Learning
} 
1. learning problems that have been identified by English teachers (for example, students fail to learn to write essays in English)

2. Strategies that have been selected to solve these problems (for example, by using Tourism Strategies). Class Room Action Research aims to solve problems by developing certain strategies.

Solving problems and developing certain strategies is the target of CAR. For that the problem that is being sought to be solved must be clearly defined and the strategy to be developed must also be clearly described. The strategy to be developed is not something that is still sought after, but something that is theoretically certain (for example, a Tourism Strategy to improve the ability to write English essays). This strategy must be explained in the form of clear learning activities. The criteria (indicators that become markers) to determine that the strategy developed has succeeded in solving the problem that is being sought for a solution must be clearly identified at the planning stage.

\section{WHAT IS CLASS ROOM ACTION REASEARCH SUCCESS CRITERIA}

The success of CAR is not only marked by increasing equal ability, but it is also marked with the acquisition value of the test given in the Class Room Action Research process. A strategy or technique developed through CAR even though it has been proven to be successful in improving students' abilities (grades increased), but if the strategy or technique, for example, is too complicated to implement, expensive or requires tools that are difficult to prepare, impractical, students do not feel happy following the learning process, the learning process does not encourage students to work together, and so on, then the strategy or technique has not been successful.

Other teachers will find it difficult to accept these strategies or techniques in their teaching activities. In other words, the more acceptable a ELR strategy or technique is by other teachers, or the higher the selling value of the strategy or technique, the higher the quality or success value of the CAR that produces the strategy or technique. So the criteria for success of Class Room Action Research in developing a ELR strategy or technique not only include the value of the test results, but also must include everything related to the ELR process.

\section{IMPLEMENTATION}

Implementation of the reseach is the implementation phase of an English learning plan that has been implemented arranged. This implementation is usually carried out 
collaboratively by the researcher with the teacher or lecturer of the English class, so that there are those who carry out learning and those who make observations, even though the teacher or lecturer implementing the study himself must also make observations.

The implementation of this learning must be done consciously in an effort to solve problems and develop a learning strategy. In implementing this learning, the teacher or lecturer may modify the action (change the design) as long as it is still in accordance with (or not moved from) the strategy being developed.

\section{OBSERVATION}

Observations are data collection activities related to learning events English language related to problem solving efforts and learning strategies that are being developed. Objects observed are events that are indicators of success (or unsuccessful) problem solving and development of strategies that are being developed. The criteria (indicators that are markers) to determine that the strategy developed has succeeded in solving the problem that is being sought solving as written in the planning stage should be the focus of observation. Because the observation stage in CAR is like the data collection stage in research other than CAR, then this stage must be prepared (discussed) data that will be collected, data collection instruments that will be used, data sources that will be extracted, and techniques data collection (will be) used. So in the Class Room Action Research results report, there is no longer a topic about Data, Research Instruments, Data Sources, and data collection techniques outside the scope of the observation stage.

In other words the discussion of data, data collection instruments, data sources, and data collection techniques must be directly related to observation activities in each cycle so that it does not give the impression that observation is an activity while data collection is another activity (outside observation). Examples of separation or disconnection between observation activities and data collection activities can be seen in the thesis, among others, by ${ }^{5}$ Indah (2002), Sujak (2002), and Suntari (2002).

In the methodology section, Indah (2002) describes two sub-topics separately, namely the research procedure sub-topic that contains planning the action, implementing the action, and reflecting the action (Pages 36-40) without including observing the action and sub-topics data and data source (page 41), data collection and instrument (pages 42-

\footnotetext{
${ }^{5}$ Indah , R.N. 2002 Enhancing Content-Area Reading Skills of the English Department Student of UIN Malang through Summary Writing
} 
45). Sujak (2002) in the methodology chapter also describes two separate sub-topics, namely the design sub-topic that contains an explanation of the CAR cycle, introduction, action preparation, action implementation, monitoring, and evaluation of reflection (pages 46-60) and data and subject sub-topics research that includes data, research subjects and settings, data collection instruments, and data analysis techniques (pages 60-76). Likewise Suntari (2002), in the methodology chapter separates between the two sub-topics of the research design that contains the research setting, preliminary studies, research subjects, collaborators, research instruments, data, techniques data analysis, and checking the validity of the data (pages 42-73) and the procedure of research activities that cover cycle 1 and cycle 2 (pages 74-84).

\section{ACTION RESEARCH (CLASS ROOM ACTION RESEARCH) DATA}

Data collected in the CAR are all symptoms or events that contain information related to predetermined success criteria. Class Room Action Research data can be in the form of quantitative data, such as test results and qualitative data, such as student learning difficulties, class atmosphere, student motivation, easy implementation of strategies or techniques that are being developed, student collaboration in learning, and so on. Because the data collected includes quantitative and qualitative data, it is not necessary to mention the use of a qualitative approach. It is enough to mention the Class Room Action Research design by involving qualitative and quantitative data.

\section{CLASS ROOM ACTION RESEARCH INSTRUMENTS}

Class Room Action Research instruments are tools that need to be prepared for observation activities. This tool is customizable with the kinds of data to be collected. The instrument for collecting data about student learning outcomes can be in the form of tests. Whereas instruments for collecting data relating to student learning difficulties, class atmosphere, student motivation, ease of implementing strategies or techniques being developed, student collaboration in learning, and so on, researchers must function as the main instrument supplemented with observation guidelines and interview guidelines.

\section{CLASS ROOM ACTION RESEARCH DATA SOURCES}

Class room action research data sources include students who are the target of action, can all students in the class or certain student samples. The classroom atmosphere given the action, the classroom in question, the teacher who collaborates in the implementation of learning, and parents of students are also sources of data. 


\section{CLASS ROOM ACTION RESEARCH DATA COLLECTION TECHNIQUES}

Class Room Action Research data collection techniques adjust to the data that has been planned for collected using instruments that have been prepared. For data about learning outcomes test techniques can be used. As for qualitative data interview and observation techniques can be used.

\section{REFLECTION}

Reflection is an activity of analyzing the results of observations to determine

1. the extent to which the development of the strategy being developed has succeeded in solving the problem and if it has not (fully) succeeded,

2. what factors are inhibiting the lack of success. Such as observation activities which include discussion of data, data sources, data collection instruments and data collection techniques; reflection activities include data analysis activities.

So the discussion about the analysis of research data must be related to or become part of the discussion of the activity (or sub-topic) reflection, so it does not give the impression that the reflection and data analysis activities are two separate activities such as those carried out by ${ }^{6}$ Indah (2002: 45), Sujak (2002 : 76) and Suntari (2002: 73).

In this reflection stage, researchers compare the results of observations with the success criteria that have been set at the planning stage. For example, Tourism Strategies will be considered successful in helping students learn to write students' English essays The requirements are :
a. students already seem happy to learn with Tourism Strategies,
b. learning implementing teachers find this strategy practical and easy,
c. students have seemed to be more active and more creative in the learning process activities,
d. students have seemed to like and can work together with friends during the learning process,
e. students seem to be more attentive to the attractions viewed, and
f. student essays show better quality .

\footnotetext{
${ }^{6}$ Indah, Sujak, Suntari, 2002 Development of Poetry Writing Creativity with Learning Strategies for Writing Poetry Formula in Class 2 SLTP Negeri Tuban.
} 
Reflection aims to assess which criteria have not been achieved and what causes the criteria have not been achieved. The criteria that have not been reached and the factors that cause them become input in the next cycle.

Thus Planning Back in cycle II departs from the problems found in cycle I (criteria that have not been achieved and the inhibiting factors). This problem looks for alternative solutions that are planned to be implemented in the next cycle. The next implementation will be observed, and reflected to determine whether there is still a need for cycle III. And so on so that the learning strategies that are being developed have succeeded in solving the problem that is being sought solving.

The number of Class Room Action Research cycles must not be limited (determined) during planning, because researchers may not already know how many cycles of learning will be able to achieve the desired success. After one cycle, if learning has produced learning targets, all indicators of success have appeared, CAR can be considered completed and reported. Conversely, even after ten cycles, if learning has not produced the learning targets as planned, not all indicators of success in learning English have been achieved, then CAR has not yet been completed and the next cycle still has to be done again.

\section{FORMULATION OF THE PROBLEM}

The research problem statement must describe the final goal to be achieved and the method research to be used. In CAR, the main objective is to develop certain strategies or techniques to solve specific problems (for learning purposes), for example: "How to apply Contextual Teaching and Learning in improving Reading Skills for SLTA N 1 Mendo Barat Students in SLTA N 1 Mendo Barat" or "How to improve Reading Skills for SLTA N 1 Students in SLTA N 1 Mendo Barat using Contextual Teaching and Learning strategy "Formulation of problems such as" How do teachers of SLTA N 1 Mendo Barat improve the students ". Reading Skills using Contextual Teaching Learning strategy "or" How is the instructional model of teaching English integratedly at SMUN N 1, Pangkal pinang ". suggests that the researcher will only describe observations in the class of others, not develop their own strategies or Contextual learning techniques. Likewise, the formulation of problems such as "How is the Student's Reading Skills after following the Contextual Teaching and Learning process" does not describe the TOD design. 
Here are 3 examples of good CAR problems in the field of English language studies Indonesian, respectively by ${ }^{7}$ Indah (2002), Sujak (2002), and Suntari (2002).

1. How is the effective model of explanation on summary writing to enhance the students' content-area reading skills? (Indah, 2002: 11)

2. Form of preparation, implementation, and evaluation of learning which can improve the process of reading critically with the SQ3R strategy in SLTP Negeri 2 Ngimbang Lamongan? (Sujak, 2002: 100).

3. "What is the process of making learning effective in developing poetry writing with the learning strategy of writing poetry-formulas in class 2 SLTP Negeri 3 Tuban?" (Suntari, 2002: 9)

\section{RESEARCH PURPOSES}

As in every other study, Class Room Action Research besides stating the formulation of the problem is also necessary state clearly the objectives to be achieved. The purpose of research always contains the same as the formulation of the problem. The statement of the same content in the two formulations, the formulation of the problem and the formulation of objectives, shows how important the role of clarity of research objectives is. Research that starts with unclear goals, or moreover is not right, will cause the research to fail. Researchers who have formulated their research goals clearly mean that they have completed $50 \%$ of their research work before the research begins. The TOD statement of purpose always uses the keyword develop ... to improve ... for example "This study aims at developing Contextual Teaching Learning strategies to improve reading skills for students of SMU N 1 Mendo Barat Poor".

Here are 3 examples of formulation of good CAR goals in the field of English and studies Indonesian, respectively by Indah (2002), Sujak (2002), and Suntari (2002). The second example and the following three will be more assertive if they do not use the word describe but use the word develop and so on.

1. This study tries to develop an effective model of explanation on Summary writing to enhance the students' content-area reading skills . (Beautiful, 2002: 12)

\footnotetext{
${ }^{7}$ Indah, Sujak and Suntari. Development of Poetry Creativity with Learning Strategies for Writing Poetry Formula in Class 2 SLTP Negeri Tuban.
} 
2. This study aims to describe the preparation, implementation, and evaluation of learning that can improve the process of critical reading with the SQ3R strategy in SLTP Negeri 2 Ngimbang Lamongan. (Sujak, 2002: 12)

3. This research aims to describe the process of effective learning in the development of writing poetry with learning strategies for writing poetry-formulas in class 2 SLTP Negeri 3 Tuban. ${ }^{8}$

\section{ACTION RESEARCH (CLASS ROOM ACTION RESEARCH) RESULTS}

Class Room Action Research results formulated as research findings or conclusions are different from the findings or research conclusions that are not Class Room Action Research results, findings or conclusions in the form of strategies or techniques that have been successfully developed are supplemented by information about the benefits of using the strategies or techniques that have been developed. Class Room Action Research results, findings, or conclusions must answer CAR questions or be in line with CAR objectives.

The conclusions formulation such as the ability to write the students of Class Room Action Research participants increased, the average ability of students is better than the average ability of students, and the travel strategy proved effective in improving the ability to write junior high school students is wrong because it does not answer the problems or goals of CAR.

In accordance with the problem or purpose, CAR generates a new strategy or technique, a strategy or technique that has certainly not been developed by other researchers in the same context. Class Room Action Research results differ from experimental research results that do not develop or do not produce a new strategy or technique, but rather compare the effectiveness level of several techniques (usually two techniques) that already exist or have been developed by other researchers.

The conclusions conveyed by Suntari (2002) do not explain the strategy itself successfully developed, but more explained that the desired strategy has been successfully developed and the strategy has succeeded in developing students' abilities. ${ }^{9}$ The process of making PKMP effective with SPMPF in class 2 SLTP Negeri 3 Tuban was successful in

\footnotetext{
${ }^{8}$ Suntari. 2002 Develoment of Poetry Writing Cretivity . State University of Malang. p.9

${ }^{9}$ Suntari 2002.
} 
accordance with the stated objectives. With SPMPF, students' poetry writing creativity can develop. The process of making PKMPF effective with SPMPF can be carried out well, from the planning, implementation stages, to the assessment of learning outcomes (Suntari, 2002: 220).

The formulation of a good CAR conclusion is exemplified by Indah (2002) as follows: "The model of direct instruction of the content area summarizing consists of three components: the explanation, the guided practice, and the independent application". ${ }^{10}$ The next description of this conclusion contains detailed steps of each component.

\section{CONCLUSION}

Actually Every teacher must have a learning problem.in his or her teaching because evry student has a different competence. A good teacher always tries solve the problem in order to successfully help students carry out learning activities. The teacher must be sure that every student will be able to successfully master the English lesson, if he gets the right help. English research is very important for teacher or lecturer in full fill their need in daily life of school or campus so they need much time and knowledge of English knowledge. Classroom Action Research is an appropriate way for teachers to find ways to help students master English lessons optimally. As a matter of fact a teacher is a very clever person in the class room so the students should follow him or her. So being a techer is not so hard but not so easy it is all depenon on the person who wanted to be a teacher.

\footnotetext{
${ }^{10}$ Indah, R.N. 2002. P. 143 Enhancing Content - Area Reading Skillof the English Department Students Of STAIN Malang through Summary Writing, State University Malang.
} 
| ZULFIKRI BETYAR RASUAN | Class Room Action Research in English Language...

\section{REFERENCES}

Bogdan, R.C. \& Biklen, S.K. 1998. Qualitative Research in Education, An Introduction to Theory and Method. Boston: Allyn and Bacon.

Borgia, E.T. \& Schuler, D. 2003. Action Research in Early Childhood Education, (on line) (http://www.ericfacility.net/ericdigests/ed401047.html), accessed .16 April 2003

Indah, R.N. 2002. Enhancing Content-Area Reading Skills of the English Department Students of STAIN Malang through Summary Writing. Unpublished thesis, Postgraduate Program, State University of Malang.

Kemmis, S. \& McTaggert, M. 1988 The Action Research Planner. (3rd ed). Victoria: Deakin University. Marshall, C. \& Rossman, G.B.1995 Qualitative Research Designing. London: SAGE Publications. Sujak 2002. Increased Critical Reading Ability with the SQ3R Strategy in Learning.

Marshall \& Rossman, 1995: 16. English Research: Qualitative Research in Education Boston University.

Reading in Class 3 SLTP Negeri Ngimbang Lamongan. Thesis not published. Program Post-graduate, State University of Malang.

Suntari. 2002. Development of Poetry Writing Creativity with Learning Strategies for Writing Poetry Formula in Class 2 SLTP Negeri Tuban. Thesis not published. Postgraduate Program, State University of Malang.

Tickman, B. W. 1999 Conducting Educational Research, Fifth Edition. Belmont: Wadsworth Group / Thomson Learning. 